\title{
Cross-Laminated Timber Shear Walls in Balloon Construction: Seismic Performance of Steel Connections
}

\author{
Hossein Daneshvar ${ }^{1 *}$, Jan Niederwestberg ${ }^{2}$, Carla Dickof ${ }^{3}$, Jean-Philippe Letarte ${ }^{4}$, and Ying Hei \\ $\mathrm{Chui}^{5}$ \\ ${ }^{1}$ Post Doctoral Fellow, Department of Civil \& Environmental Engineering, University of \\ Alberta, Canada \\ ${ }^{2}$ Research Associate, Department of Civil \& Environmental Engineering, University of Alberta, \\ Canada \\ ${ }^{3}$ Senior Technical Specialist, Fast+Epp, Canada \\ ${ }^{4}$ Mass Timber Connections Specialist, MyTiCon Timber Connectors, Canada \\ ${ }^{5}$ Professor, Department of Civil \& Environmental Engineering, University of Alberta, Canada \\ "Corresponding author's e-mail: hossein.daneshvar@ualberta.ca
}

\begin{abstract}
In the context of the global trend of designing sustainable structures, the attention towards highrise timber buildings of 8 to 25 storeys has been increasing in recent years. Balloon construction technique using a relatively new heavy timber material, cross-laminated timber (CLT), has been shown to be promising for high-rise building applications, given its compatibility with off-site construction techniques and its desirable mechanical characteristics. To date, tall timber buildings using CLT have been built mainly in non-seismic or low-seismic locations around the world, whereas their application in high seismic regions has been limited to platform construction. More research on the behaviour of CLT structures during seismic events in terms of system behaviour as well as the behaviour of components, particularly connections, is required. The research presented in this paper seeks to initiate the process of seismic design of tall wood buildings using a balloon construction technique. Two buildings, one three-storey fictitious building and one tobe-constructed ten-storey building, both located on the west coast of Canada, were considered and designed based on the NBCC 2015 seismic provisions. The loads on the shear walls, which span over three storeys, were extracted in order to estimate realistic demands on lateral load resisting systems (LLRS) in the balloon construction. Different connections, including base shear connections, panel-to-panel shear connections, as well as high-capacity hold-downs, were designed accordingly. An experimental program was developed to investigate the behaviour of these connections, focusing on yielding and failure mechanisms in each connection category. This paper explains different phases of the experimental program and introduces connection details designed to achieve the research goals. The results of this study will contribute to the body of knowledge on seismic behaviour of prefabricated mass timber buildings, and will benefit engineers and practitioners using timber to design high-rise structures.
\end{abstract}

\section{KEYWORDS}

Cross-laminated timber (CLT); Lateral load resisting system (LLRS); Balloon construction; Seismic design; Connections. 
MOC SUMMIT / MAY 2019

\section{INTRODUCTION}

There has been a global trend in recent years towards designing sustainable high-rise buildings of more than 8 storeys using wood as the main structural material with. The 18-storey Brock Commons Building, located in Vancouver, BC, currently the tallest hybrid mass timber building in the world, is a successful showcase for timber construction. This building possesses unique features and demonstrates the capacity of mass timber products in high-rise buildings in terms of strength and constructability. It is a challenging task, it should be noted, to design earthquakeresisting LLRS out of timber, particularly for high seismicity areas such as Vancouver. A key advantage of using mass timber for the Brock Commons building was the speed of installation of the structural components. However, the elevator and staircase cores of the building responsible for transferring the lateral loads to the foundation were made of reinforced concrete, adding delays related to concrete formwork preparation and curing time. The balloon framing system possesses the advantages of raising the structural component up to 3-storeys at a time, decreasing construction time, and reducing exposure of elements to weather. Increasing the height of the timber lateral systems significantly, though, increases the forces at connection points, creating a new challenge for designers. CLT is a relatively new mass timber material that has been found to be promising for high-rise LLRS applications considering their mechanical characteristics in shear wall systems, as shown in Figure 1.

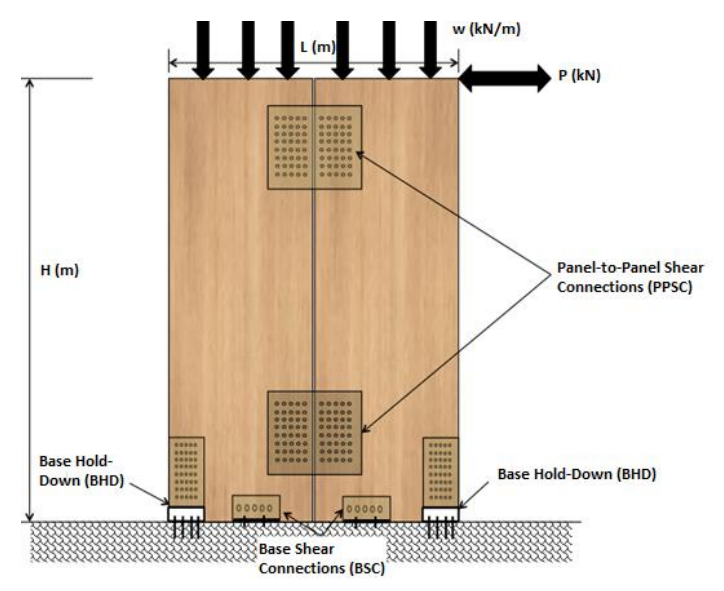

Figure 1. CLT shear wall in balloon construction and its prevalent connections under consideration

The use of CLT shear walls in platform construction has recently been incorporated into Canada's timber design code, CSA O86 (CSA 2014); however, its application in balloon construction has not received much attention from researchers. Although O86-14 (CSA 2014) acknowledges the system, more investigations on the behaviour of CLT walls during seismic events are required. Both the system behaviour and the behaviour of the energy-dissipating connection components require further study to help validate the use of wood in tall buildings in seismically active regions. The presented study seeks to initiate experimental assessment of such connections under monotonic and cyclic loading. After a brief literature survey, two sample buildings used to establish the load range are discussed, followed by a brief introduction to the project, and a description of the connections under investigation, the testing program, and the test setup designed. Finally the intended outcome is presented. 
MOC SUMMIT / MAY 2019

\section{SELECTED PREVIOUS RESEARCH}

Smith et al. (2006) classified timber components based on their ductility, which is "mostly a function of the connection characteristics", into four groups: brittle, low ductility, moderateductility, and high-ductility. A review of current codes, guidelines, and the current state-of-the-art body of knowledge has revealed that there is no unified classification of connections in terms of ductility (CSA 2014), meaning that the methods of estimation of yield point and definition of ultimate load vary according to different references (Munoz et al. 2008). Previous research on CLT wall systems in platform construction showed that the majority of inelastic behaviour induced during a major earthquake event are expected to occur at the connections, while CLT panels behave rigidly (Dujic et al. 2006; Popovski et al. 2010; Popovski and Karacabeyli 2012a; 2012b; Gavric 2012; Gavric et al. 2013). As a general rule, taking into account the connection characteristic behaviour is crucial in the analysis and design of CLT buildings, with the post-yield behaviour of connections being of particular importance for seismic forces (Fragiacomo et al. 2011; Rinaldin and Fragiacomo 2016). Characteristics of connection behaviour, such as flexibility and ductility, in the linear and nonlinear analyses, respectively, play an important role in achieving reliable results (Sustersic et al. 2016).

Tomasi and Smith (2015) investigated the performance of a range of commercially manufactured steel bracket connections as well as special custom-made connectors under monotonic and cyclic loadings. They concluded that the behaviour of the connections investigated is too complicated to be determined by simplified analytical methods and that experiments are the only reliable tool to determine design parameters. Several other studies (Popovski and Karacabeyli 2012a, 2012b; Karacabeyli and Douglas 2013; Schneider et al. 2015; Gavric et al. 2015) have sought to initiate the process of evaluating the behaviour of CLT connections in tension or shear under monotonic and cyclic loads. The majority of the connections tested to-date possess low ultimate capacities within a range of less than $100 \mathrm{kN}$, applicable to low or medium-rise buildings. As the height of the structure increases, though, the forces induced increase significantly as the overall overturning forces increase. As a result, the energy-dissipating connections should be given special attention during the design phase. Despite previous efforts to design ductile high-capacity connections (Zhang et al. 2018), the current body of knowledge is in its infancy with regard to the systems under study here. As a result, it is vital to test the behaviour of the structural systems, with particular emphasis on their connections, to ensure their satisfactory performance during a seismic loading scenario.

\section{PROTOTYPE BUILDINGS}

In order to develop realistic loads for the connection design, two buildings are considered. The first is a fictitious three-storey timber structure built on top of a one-storey concrete podium, located in the high seismicity area of Victoria, BC. The LLRS of the building consists of CLT shear wall central core systems, built using balloon construction, spanning three storeys (see Figure 2). Site class type $D$, a normal importance category, and an $R_{d} R_{o}$ of 3 are assumed based on NBCC (2015) for preliminary seismic load calculations. The second building, shown in Figure 3(a), is a ten-storey timber building currently being designed and to be located in Vancouver, BC. It consists of four levels of underground parking as well as a one-storey concrete podium supporting 10 storeys of timber framing. The LLRS will consist of perimeter timber braced frames (shown in 
orange in the figure) combined with internal CLT shear walls (shown in red). The floor plan is shown in Figure 3(b). A normal importance category and an $R_{d} R_{o}$ of 3 are assumed for the seismic load calculation based on NBCC (2015). The validity of the assumed seismic loads will be verified by means of nonlinear dynamic analysis after determination of the connection responses.

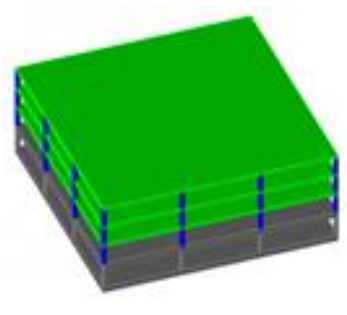

(a)

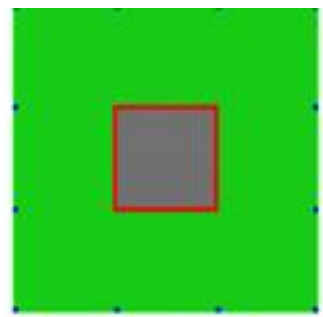

(b)

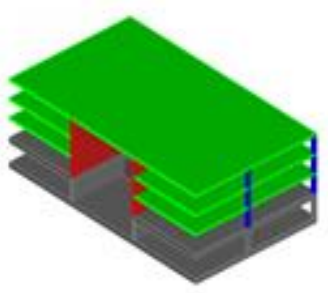

(c)

Figure 2. Prototype building 1: (a) 3-D view (b) plan view (c) 3D section through CLT Shear wall cores

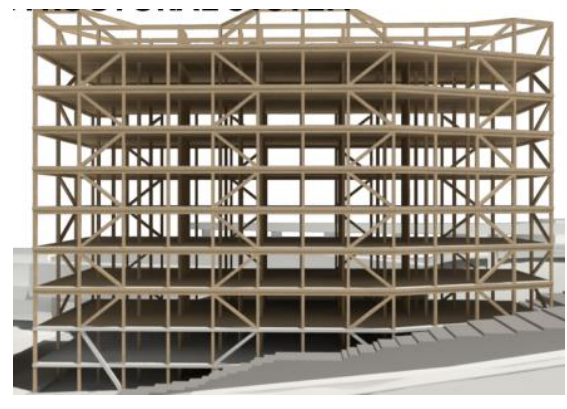

(a)

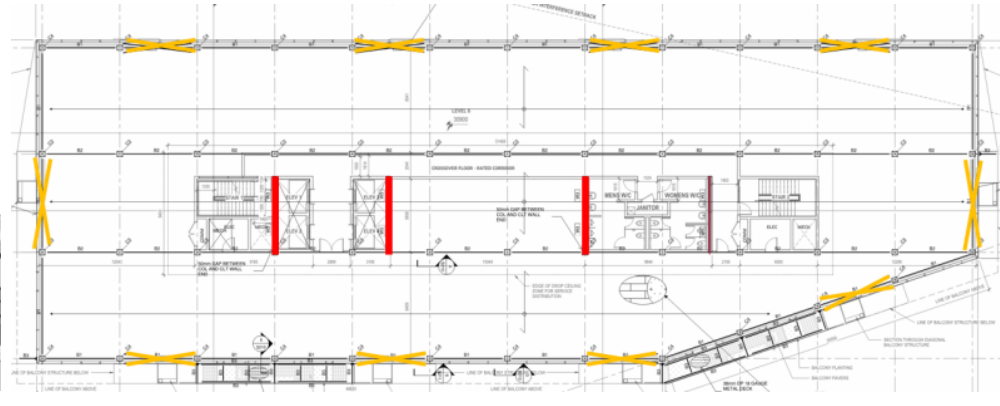

(b)

Figure 3. Prototype building 2: (a) 3-D view (b) plan view

\section{PROPOSED EXPERIMENTAL PROGRAM}

The Advanced Research in Timber Systems (ARTS) research group at the University of Alberta, in conjunction with the NSERC Industrial Research Chair (IRC) in Engineered Wood \& Building Systems, is conducting a project on the seismic behaviour of CLT tall wall buildings. ARTS has also partnered with Fast + Epp and MyTiCon designing an experimental program to generate data that will be used in the design of the ten-storey mass timber building discussed earlier. The experimental program consists of three phases, outlined below:

Phase 1 - Small scale connection tests
a) CLT panel-to-panel (spline) connection tests
b) CLT panel hold-down connection tests
c) CLT base shear connection

Phase 2 - Large scale connection tests

a) CLT hold-down connection tests - large scale CLT panel

Phase 3 - Full scale system tests

a) Two storey double-panel CLT shear wall test 
Table 1 shows the developed testing program as a part of tall wall project (Figure 4).

Table 1. Summary of proposed experimental program for tall wall project

\begin{tabular}{|c|c|c|c|c|c|c|}
\hline \multirow{2}{*}{\multicolumn{2}{|c|}{$\begin{array}{c}\text { Connection } \\
\text { Category }\end{array}$}} & \multirow{2}{*}{ Type } & \multirow{2}{*}{$\begin{array}{l}\text { Test Setup } \\
\text { Summary }\end{array}$} & \multirow{2}{*}{ Test Capacity } & \multicolumn{2}{|c|}{ Number of Tests } \\
\hline & & & & & Mono. & Cyclic \\
\hline \multirow{6}{*}{$\begin{array}{c}\text { Phase } \\
1\end{array}$} & \multirow{2}{*}{$\begin{array}{l}\text { Panel-to- } \\
\text { panel }\end{array}$} & Type 1 & \multirow{2}{*}{$\begin{array}{l}3 \text { panels and } 2 \\
\text { connectors }\end{array}$} & $115 \mathrm{kN}$ & 1 & 2 \\
\hline & & $\begin{array}{l}\text { Type 2: different } \\
\text { arrangement }\end{array}$ & & $115 \mathrm{kN}$ & 1 & 2 \\
\hline & \multirow{2}{*}{$\begin{array}{l}\text { Hold- } \\
\text { down }\end{array}$} & Type 1 & \multirow{2}{*}{$\begin{array}{l}2 \text { panels and } 1 \\
\text { central connector } \\
\text { connected to } \\
\text { both panels }\end{array}$} & $792 \mathrm{kN}$ & 1 & 2 \\
\hline & & $\begin{array}{l}\text { Type 2: reduced } \\
\text { capacity }\end{array}$ & & $400 \mathrm{kN}$ & 1 & 2 \\
\hline & \multirow{2}{*}{$\begin{array}{l}\text { Base shear } \\
\text { connection }\end{array}$} & Type 1 & \multirow{2}{*}{$\begin{array}{l}2 \text { panels and } 4 \\
\text { connectors }\end{array}$} & $380 \mathrm{kN}$ & 1 & 2 \\
\hline & & $\begin{array}{l}\text { Type 2: different } \\
\text { connection type }\end{array}$ & & $280 \mathrm{kN}$ & 1 & 2 \\
\hline $\begin{array}{c}\text { Phase } \\
2 \\
\end{array}$ & $\begin{array}{l}\text { Hold- } \\
\text { down }\end{array}$ & Type 1 & $\begin{array}{l}1 \text { central panel } \\
\text { and } 2 \text { connectors }\end{array}$ & $3012 \mathrm{kN}$ & 0 & 2 \\
\hline $\begin{array}{c}\text { Phase } \\
3\end{array}$ & CLT wall & \multicolumn{2}{|c|}{ TBD } & $\begin{array}{l}\text { Less than } 5,000 \\
\text { kN base shear }{ }^{1}\end{array}$ & \multicolumn{2}{|c|}{2 each } \\
\hline
\end{tabular}

${ }^{1}$ In addition: Maximum allowable applied load on transfer beam: 3,000 kN; Maximum allowable overturning moment at base: $20,000 \mathrm{kN} \cdot \mathrm{m}$

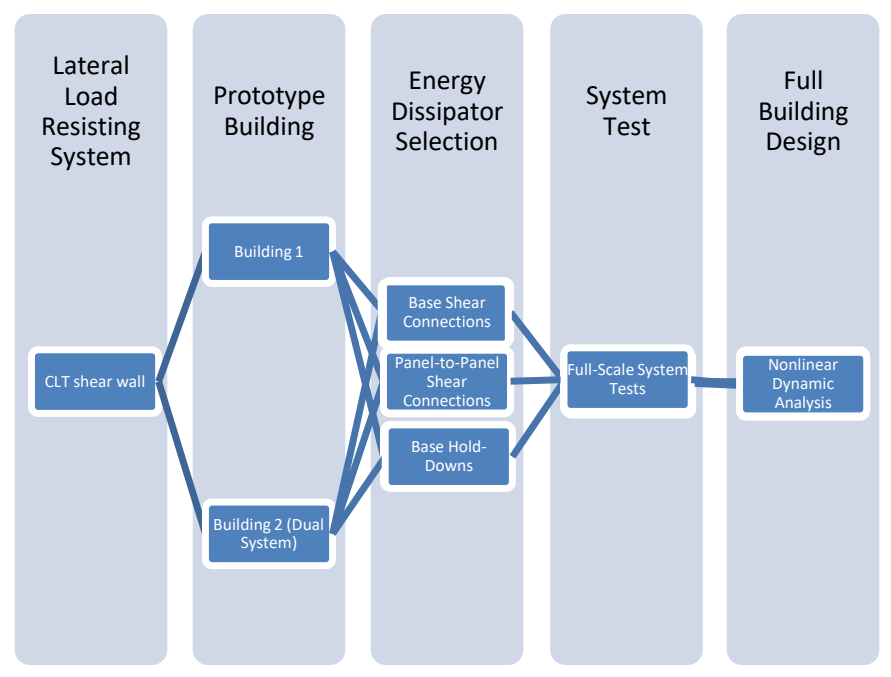

Figure 4. Tall wall project at a glance

The main concept underlying the connection design is to impose all shear yielding on the steel plate elements of the connections in order to achieve reliable ductile behaviour while the doweled connection between the steel plates and CLT panels are capacity-protected. In order to ensure the desired yielding mode, perforated steel plates were chosen to achieve a designated dissipative zone and tuned to achieve specific yield strengths. The test setups for base shear connections, panel-to- 
panel, and base hold-downs are shown in Figures 5 to 7, respectively. The connections will be tested under both monotonic and cyclic loading regime based on ASTM E2126 standard (2018).

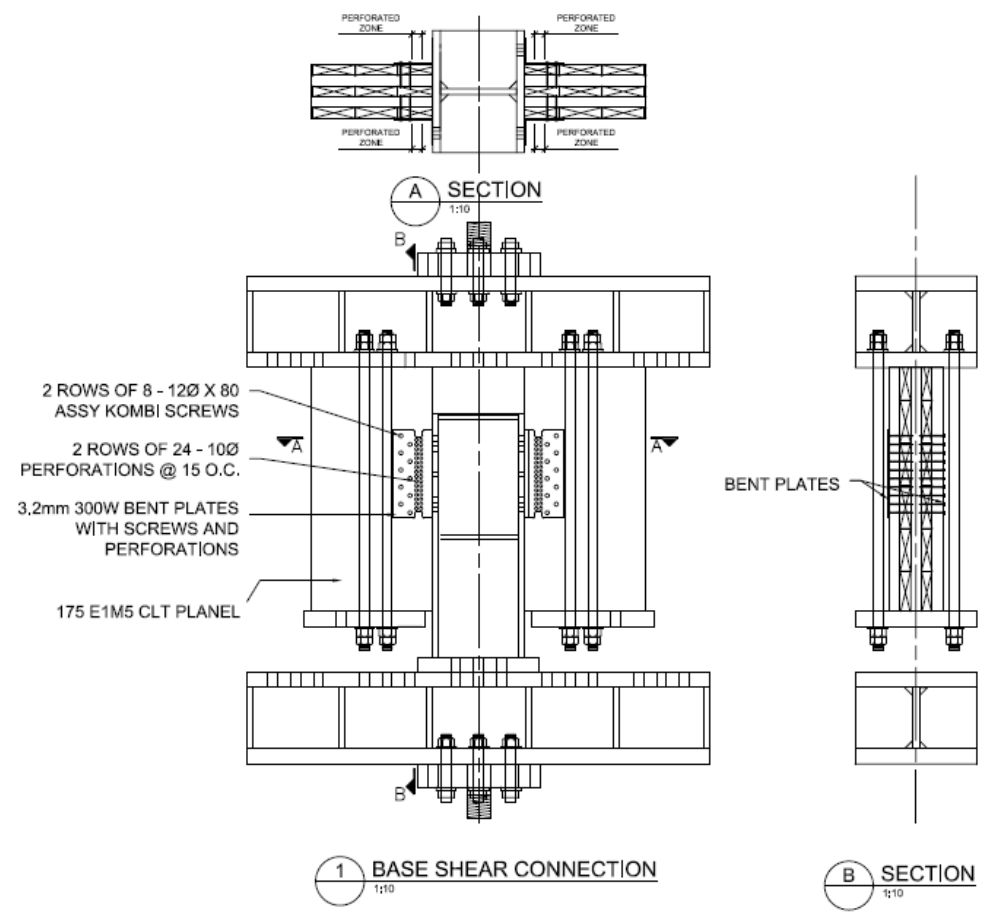

Figure 5. Phase 1: Base shear connection test setup

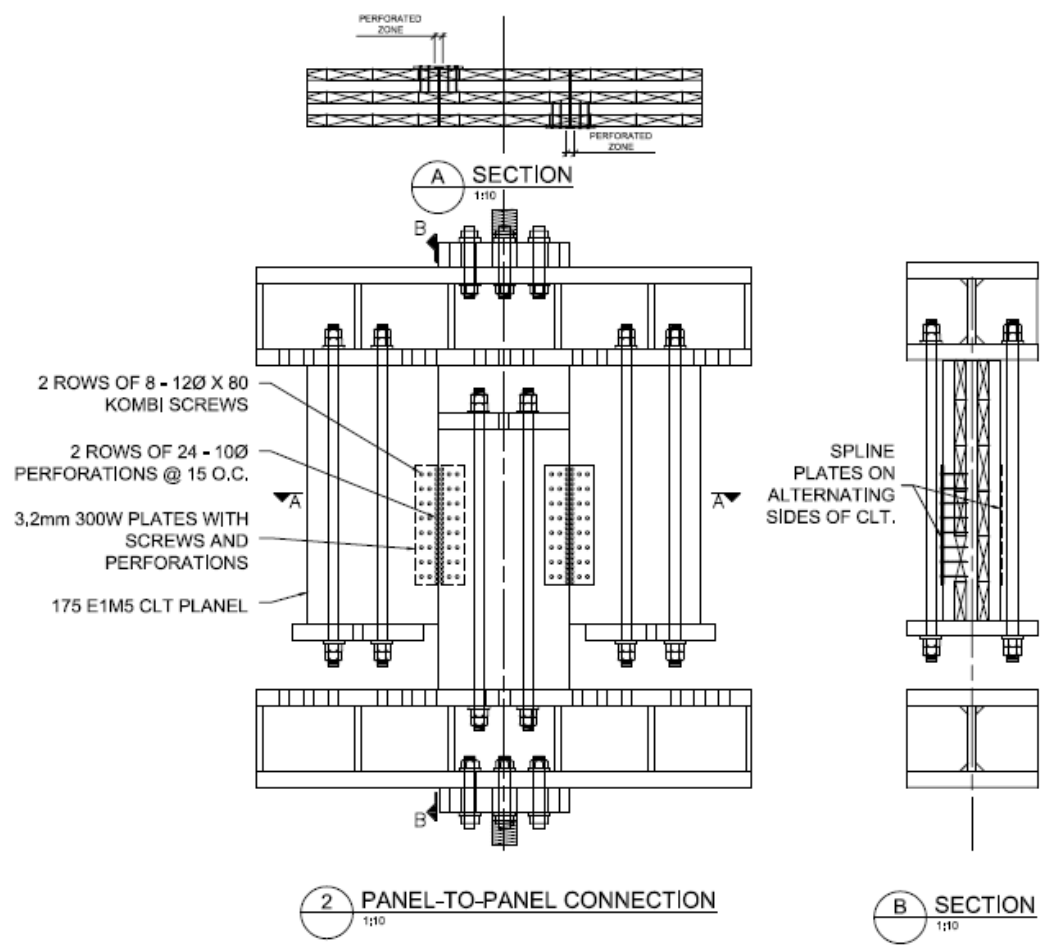

Figure 6. Phase 1: Panel-to-panel connection test setup 

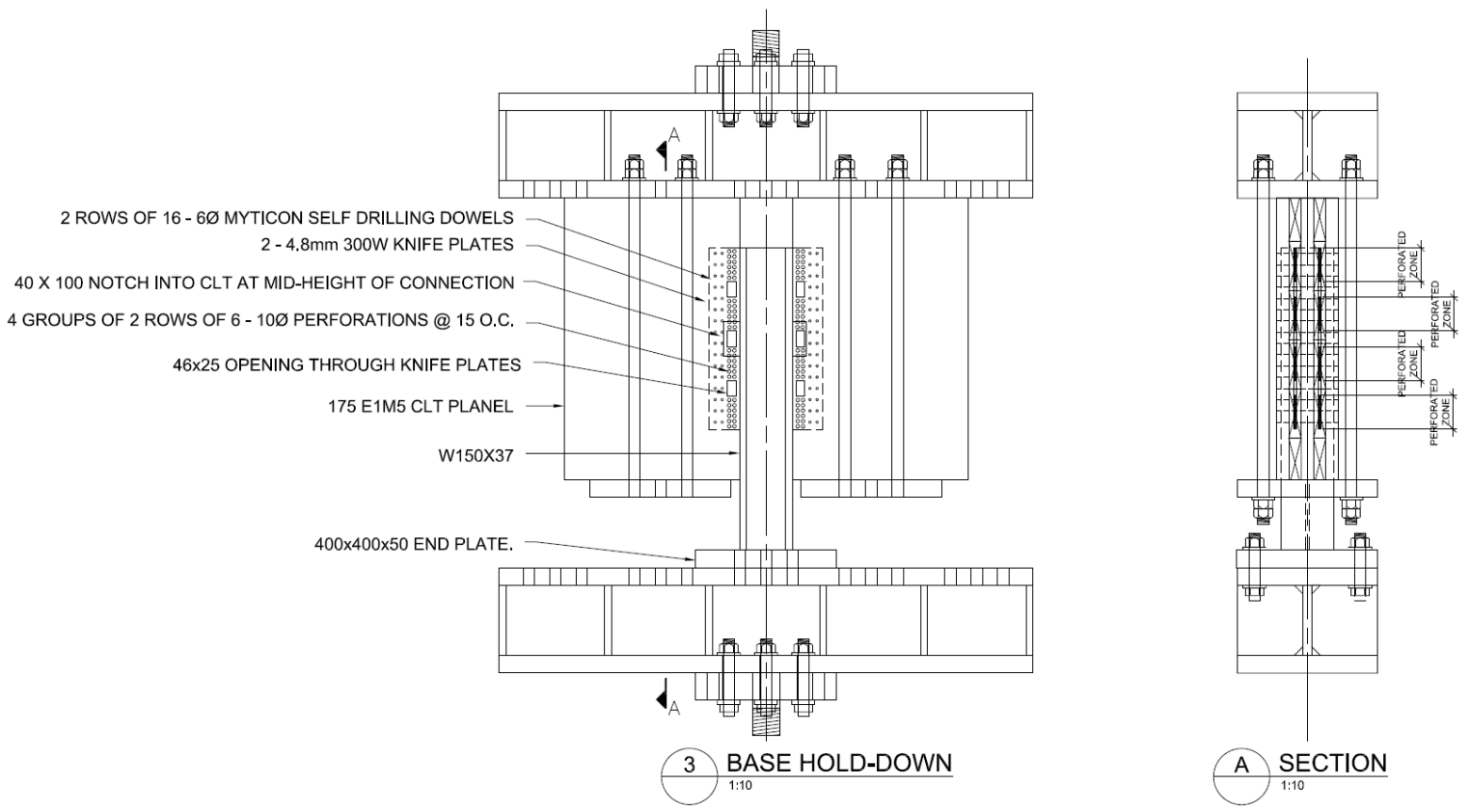

Figure 7. Phase 1: Base hold-down connection test setup

\section{EXPECTED OUTCOME}

Connections with perforated steel plates are capable of dissipating energy in shear yielding by demonstrating ductile behaviour in both monotonic and cyclic loadings. The testing program, results pending, is expected to shed more light on the connection performance in terms of strength, ductility, stiffness, and energy dissipation. It is expected that the results of this study will be used in future work performing nonlinear analyses of buildings that use balloon construction and CLT shear wall systems as a LLRS, whether as a stand-alone system or in conjunction with another system, e.g., a braced frame to form a dual LLRS.

\section{ACKNOWLEDGEMENTS}

The authors would like to acknowledge the support of the Natural Sciences and Engineering Research Council of Canada (NSERC), through the Industrial Research Chair program as well as the Natural Resources Canada (NRCan) GCWood program in conjunction with Bentall Kennedy; courtesy of Fast + Epp. Thoughtful insights from Robert Jackson, project manager at Fast + Epp, and Max Closen, Technical Advisor at MyTiCon, are also greatly appreciated.

\section{REFERENCES}

ASTM E2126. (2018). Standard Test Methods for Cyclic (Reversed) Load Test for Shear Resistance of Vertical Elements of the Lateral Force Resisting Systems for Buildings, ASTM International, West Conshohocken, PA.

Canadian Standards Association (2014). Engineering design in wood. CSA Standard 086-14, Toronto, ON, Canada. 
Dujic, B., Aicher S., and Zarnic R. (2006). Testing of Wooden Wall Panels Applying Realistic Boundary Conditions. Proceedings of the $9^{\text {th }}$ World Conference on Timber Engineering, Portland, Oregon, USA.

Fragiacomo, M., Dujic B., and Sustersic, I. (2011). Elastic and ductile design of multi-storey crosslam massive wooden buildings under seismic actions. Engineering Structures, Special Issue on Timber Structures, 33(11), 3043-3053.

Gavric I. (2012). Seismic Behaviour of Cross-Laminated Timber Buildings. Ph.D. Thesis. Universita degli studi di Trieste. Trieste, Italy.

Gavric, I., Fragiacomo, M., Popovski, M., Ceccotti, A. (2013). Behaviour of cross-laminated timber panels under cyclic loads. RILEM Conference on Materials and Joints in Timber Structures, Stuttgart, Germany.

Gavric I., Fragiacomo M., Ceccotti A. (2015). Cyclic behaviour of typical metal connectors for crosslaminated (CLT) structures. Materials and Structures. 48(6), 1841-1857.

Karacabeyli, E. and Douglas, B. (2013). CLT Handbook. FPInnovations, US edition.

Popovski, M., Schneider, J., Schweinsteiger, M. (2010). Lateral Load Resistance of CrossLaminated Wood Panels. Proceedings of the $11^{\text {th }}$ World Conference on Timber Engineering, Riva del Garda, Italy.

Popovski, M., Karacabeyli E. (2012a). Seismic Behaviour of Cross-Laminated Timber Structures. Proceedings of the $12^{\text {th }}$ World Conference on Timber Engineering, Auckland, New Zealand.

Popovski, M. and Karacabeyli, E. (2012b). Seismic Behaviour of Cross-Laminated Timber Structures. Proceedings of the $15^{\text {th }}$ World Conference on Earthquake Engineering, Lisbon, Portugal.

Munoz, W., Mohammad, M., Salenikovich, A., and Quenneville, P. (2008). Need for a harmonized approach for calculations of ductility of timber assemblies. Proceedings of the $41^{\text {st }}$ Meeting of the Working Commission W18-Timber Structures, St. Andrews, NB, Canada.

NBC (2015). National Building Code of Canada 2015. Canadian Commission on Building and Fire Codes. National Research Council. Ottawa, ON, Canada.

Rinaldin, G. and Fragiacomo, M. (2016). Non-linear simulation of shaking-table tests on 3- and 7storey X-Lam timber buildings. Engineering Structures, 113, 133-148.

Smith, I., Chui, Y. H., and Quenneville, P. (2006). Overview of a new approach to handing system effects in timber structures. Proceedings of the International Council for Research and Innovation in Building and Construction, Working Commission W18 - Timber Structures. Florence, Italy.

Sustersic, I., Fragiacomo, M., and Dujic, B. (2016). Seismic analysis of Cross-Laminated multistory timber buildings using code-described methods: Influence of panel size, connection ductility, and schematization. Journal of Structural Engineering, 142(4), E4015012.

Schneider, J., Shen, Y., Stiemer, S.F., Tesfamariam, S. (2015). Assessment and comparison of experimental and numerical model studies of cross-laminated timber mechanical connections under cyclic loading. Construction and Building Materials, 77, 167-212.

Tomasi, R., Smith, I. (2015). Experimental characterization of monotonic and cyclic loading responses of CLT panel-to-foundation angle bracket connections. Journal of Materials in Civil Engineering, 27(6), 04014189.

Zhang, X. Popovski, M., and Tannert, T. (2018). High-capacity hold-down for mass-timber buildings. Construction and Building Materials, 164, 688-703. 